\title{
Stochastic Simulation of Production Processes - Selected Issues
}

\section{Ryszard SNOPKOWSKI ${ }^{1)}$, Marta SUKIENNIK'), Aneta NAPIERAJ ${ }^{3)}$}

\footnotetext{
1) Prof. dr; AGH University of Science and Technology in Krakow, Mickiewicza 30, 30-059 Kraków, email: snopkows@agh.edu.pl

2) dr, prof. AGH, AGH University of Science and Technology in Krakow, Mickiewicza 30, 30-059 Kraków, email: marta.sukiennik@agh.edu.pl

3) dr, AGH University of Science and Technology in Krakow, Mickiewicza 30, 30-059 Kraków, email: agrodek@agh.edu.pl
}

http://doi.org/10.29227/IM-2021-01-18

Submission date: 17-01-2021 | Review date: 29-05-2021

\section{Abstract}

The article presents selected issues in the field of stochastic simulation of production process-es. Attention was drawn to the possibility of including, in this type of models, the risk accompany-ing the implementation of processes. Probability density functions that can be used to characterize random variables present in the model are presented. The possibility of making mistakes while creat-ing this type of models was pointed out. Two selected examples of the use of stochastic simulation in the analysis of production processes on the example of the mining process are presented.

Keywords: stochastic simulation, production process, probability density function

\section{Introduction}

According to generally adopted definitions (e.g. Robinson 2004), to simulate means to mimic or imitate a real system by means of experiments conducted on a model representing (presenting) that system.

Simulation, however, is not just about imitation and experimentation. It also assumes defin-ing, designing, and building a model, as well as defining the experiments that will be run and col-lecting and analyzing the data needed to run the model along with analyzing and interpreting the results obtained from the experiments.

People all over the world are currently in a constant search for ways to reduce costs and make optimal use of resources. Achieving this in a dynamic, complex and interconnected global environ-ment is undoubtedly a challenge. Organizations are looking for lean system solutions to slim down their operations by eliminating everything that does not bring value to the customer while stream-lining the manufacturing process. They prepare value stream maps, identifying where time wasters and human effort occur. Optimization is treated as a key to success today (Beaverstock et. al. 2012).

Managers who make decisions in organizations need to know what is happening in their sys-tems, as well as what will happen in their systems and what actions need to be taken against those changes. A basic definition of a system characterizes it as a collection of interrelated elements with-in defined boundaries (Checkland 1981). In practice, the system can be very elaborate and represent a factory or organization, or quite simple, when it characterizes a workstation, an emergency room in a hospital, or a service desk at a bank. Decision-making is easy in simple systems and in situations with limited choice. However, more complex systems usually offer a large number of options for action.

Analyzing and making the right decision in the course of a manufacturing process is difficult because each system has one or more features, the general characteristics of which are as follows (Beaverstock et. al. 2012):

1. System components may be subject to random events.

2. Ambient random events affect the system.

3. The behavior of the system is dependent on an essential variable - time.

4. System elements encompass many interactions, and therefore there are many ways to con-nect paths between system elements.

Random events are common in manufacturing systems. These can include machine failures, operator response time to an incident, material delivery time and material losses, etc. When a man-ager proceeds to analyzing a system and formulates a plan to optimize its performance, they may encounter extremely difficult problems. Traditional analytical methods may not be sufficient in view of the dynamic and random nature of the system's behavior. Therefore, methods have been devel-oped to help managers analyze processes and are commonly known as decision support systems (Beaverstock et. al. 2012).

A decision support system applies analysis tools to help the decision maker formulate action plans. Simulation is one of them. Simulation (Robinson 2004) is defined as experimentation and simplified imitation (computer-assisted) of a specific action. It provides mechanisms for exploring the system presented in it, alternatively experimenting and predicting the outcome of proposed ex-ternal solutions. This approach significantly increases the decision space (allows for evaluating a greater number of different ideas), does not interfere with the actual system, and allows for estimat-ing the risk of actions. Managerial activities will be more effective if simulation modeling applica-tions are embedded in decision support systems, as this facilitates data entry into the model and improves the presentation of the resulting model. 
Fig. 1. Errors, inaccuracies and their verification capabilities in a stochastic simulation

Rys. 1. Błędy, niedokładności i możliwości ich weryfikacji w symulacji stochastycznej

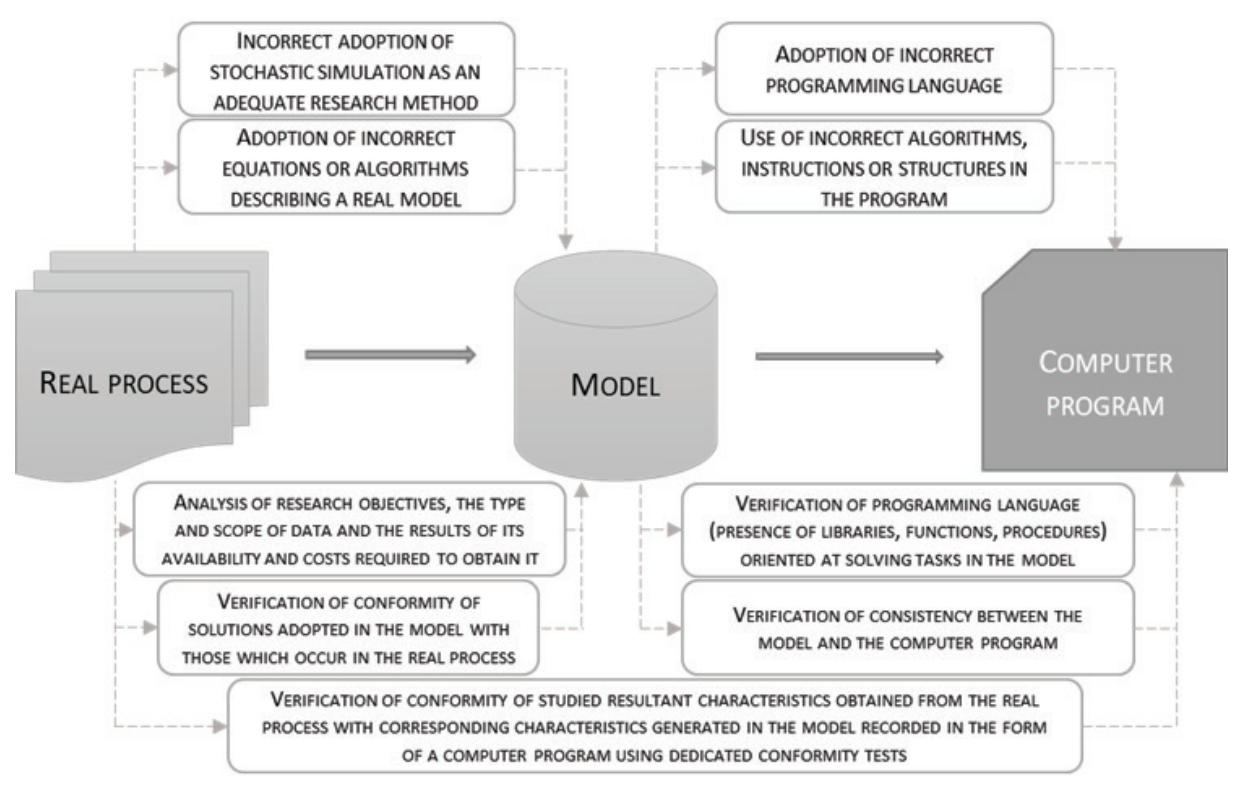

\section{Stochastic simulation}

In this paper, special emphasis is placed on stochastic simulation. This method is used for computer modeling of any processes (physical, economic, technological, etc.) or their fragments, whose characteristic feature is the presence of at least one random variable in their description.

The method was first used during the Manhattan Project research to build the U.S. atomic bomb. The stochastic model developed at that time concerned the analysis of neutron propagation in a nuclear reactor. It was developed jointly by John von Neumann and Stanisław Ulam, a Polish mathematician.

The stochastic simulation method has been successfully used until today. The possibilities of creating complex stochastic models, their recording in the form of a computer program in a language oriented at solving this type of problems, as well as the constantly improving capabilities of comput-ers, all determine the choice of stochastic simulation as a method of solving problems described by models of an undetermined nature.

The current state of development of computer technology makes it possible to create accurate mathematical and economic models that can be used in decision-making processes applicable to programming, design and production planning.

Computational methods referred to as Monte Carlo are closely related to stochastic simula-tions. They involve using "artificially generated" randomness to solve deterministic tasks. Monte Carlo methods are relatively simple and efficient, and, for some problems, they are the only compu-tational tool available. Stochastic simulations are available to everyone due to the availability of free and open source software that allows any computer user to use such tools. As an example, the $\mathrm{R}$ language is a powerful tool (see Niemiro 2013).

The literature is very extensive, and one can mention works in the field of random number generators (e.g. Zielinski, Wieczorkowski 1997), and a monograph (Ripley 1987) which also includes an introduction to the Monte Carlo methods. Advanced lectures can be found in modern mono-graphs by Asmussen and Glynn (Asmussen, Glynn 2007), Liu (Liu 2004), Robert and Casella (Rob-ert, Casella 2004). The former is more oriented towards theoretical results, while the latter is more oriented towards applications. An introduction to Markov Chain Monte Carlo methods is included in the work of Geyer (Geyer 1992, Geyer 2005). The Markov chain theory with issues relevant to Mar-kov Chain Monte Carlo is also presented by Brémaud (Brémaud 1999). The theoretical basis for the analysis of randomized algorithms can be found in the work of Jerrum and Sinclair (Jerrum, Sinclair 1996) and Jerrum (Jerrum 1998), among others.

The use of stochastic simulation - as a research method - can be accompanied by errors or in-accuracies, which are illustrated in Figure 1. Individual terms mean: a real process is a process that is being studied by a simulation method; a model is a set of equations, inequalities, and/or algorithms that have been adopted as a mathematical description of the real process; a computer program is a notation of the model in a programming language of choice. Apparently minor mistake - made at the stage of building a model, writing it in the form of a computer program, or its verification - can be costly in its consequences. An analysis of such activities is presented in (Snopkowski 2009).

\section{Distributions used in process description}

Random variables occurring in process models (including for manufacturing processes) are characterized by appropriate probability density functions. What is also noteworthy, the existing functional relationships between random variables can be replaced by a single probability density function (the so-called result distribution), which causes that the developed stochastic model of the analyzed process is simplified (Snopkowski 2005a, Snopkowski 2005b).

Examples of probability density functions used in simulation models are summarized in Table 1.

\section{Use of simulation in the analysis of manufacturing processes}

Making decisions concerning business activity in the environment of market economy requires the manager to 


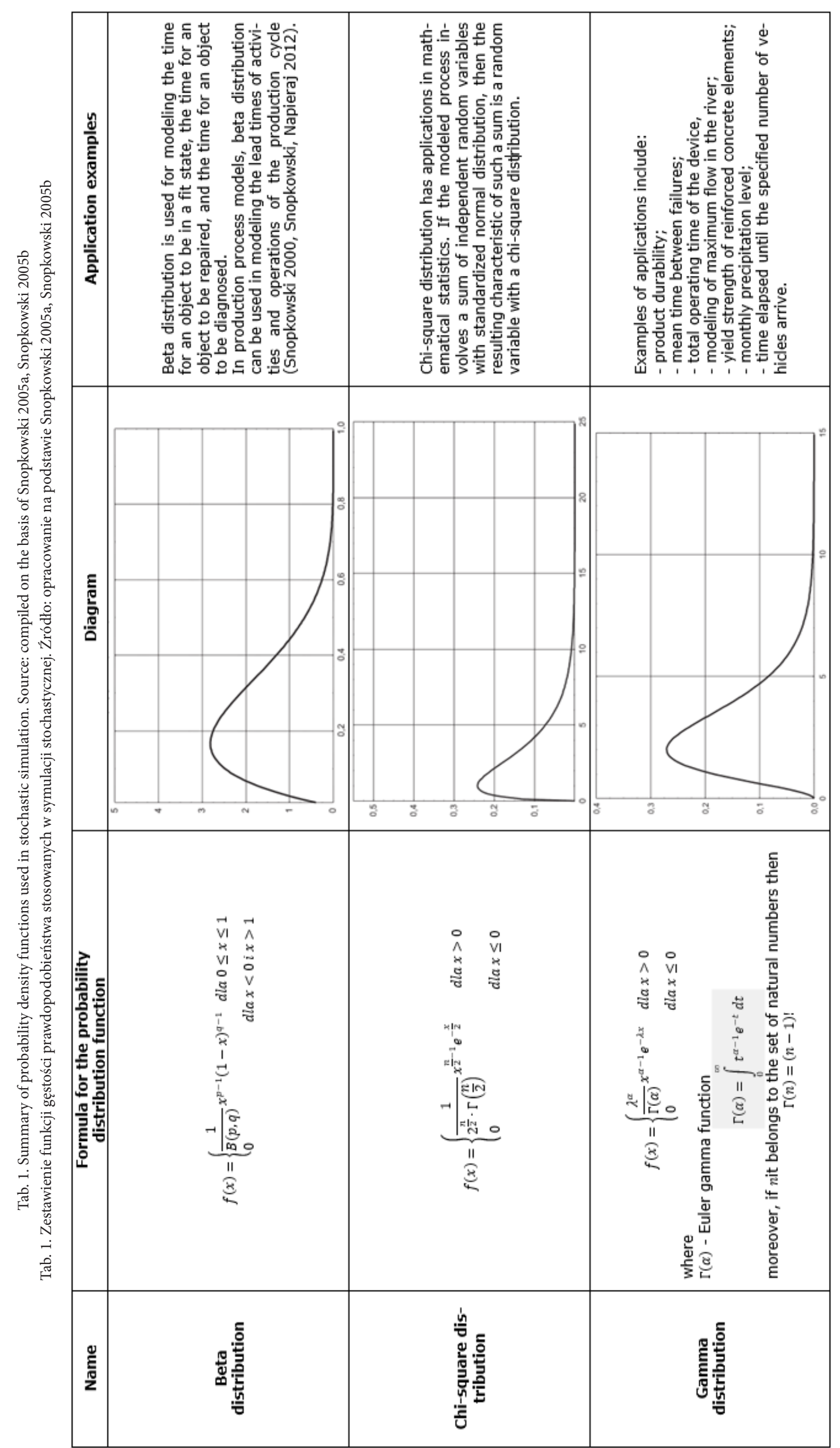




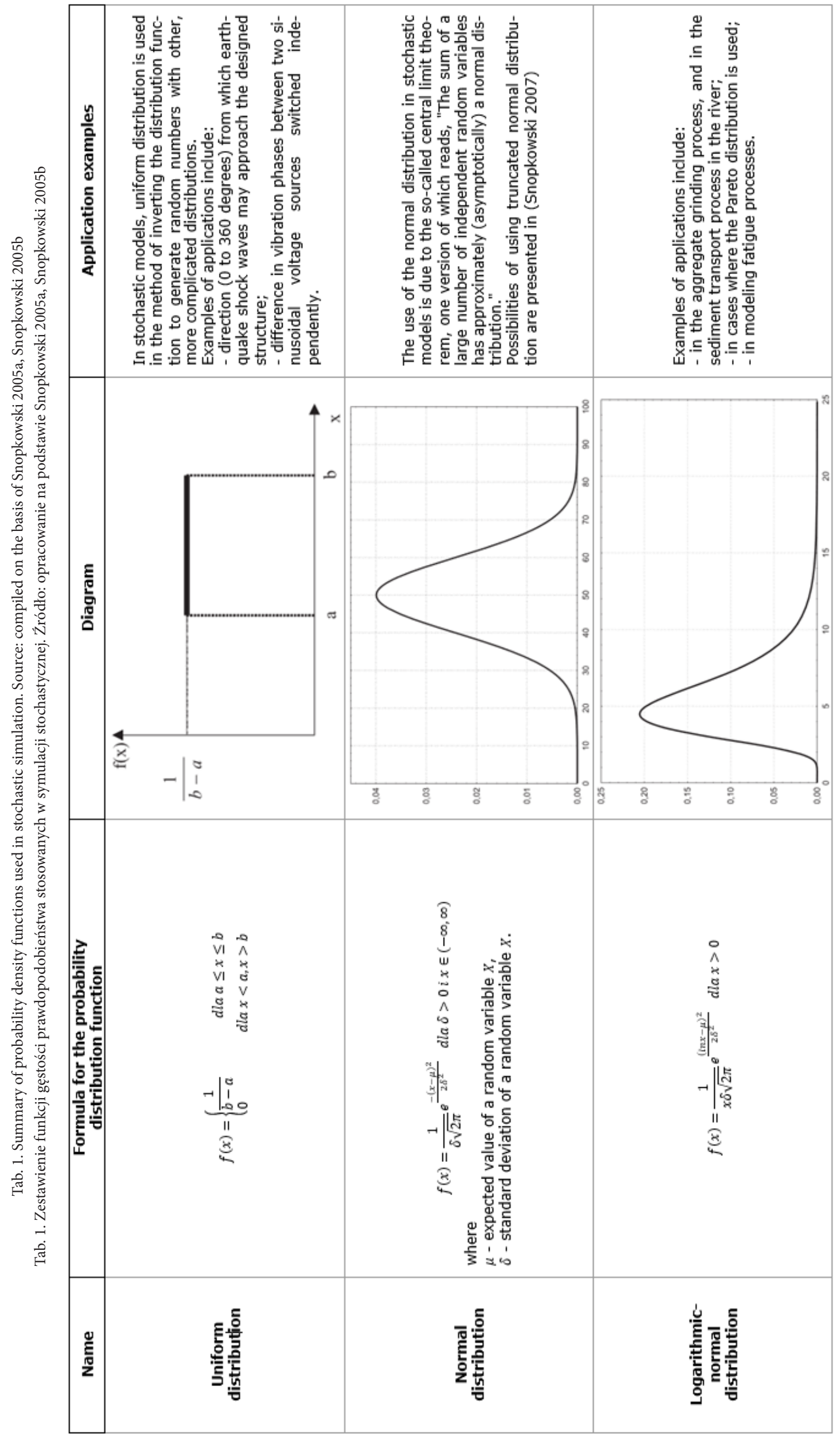




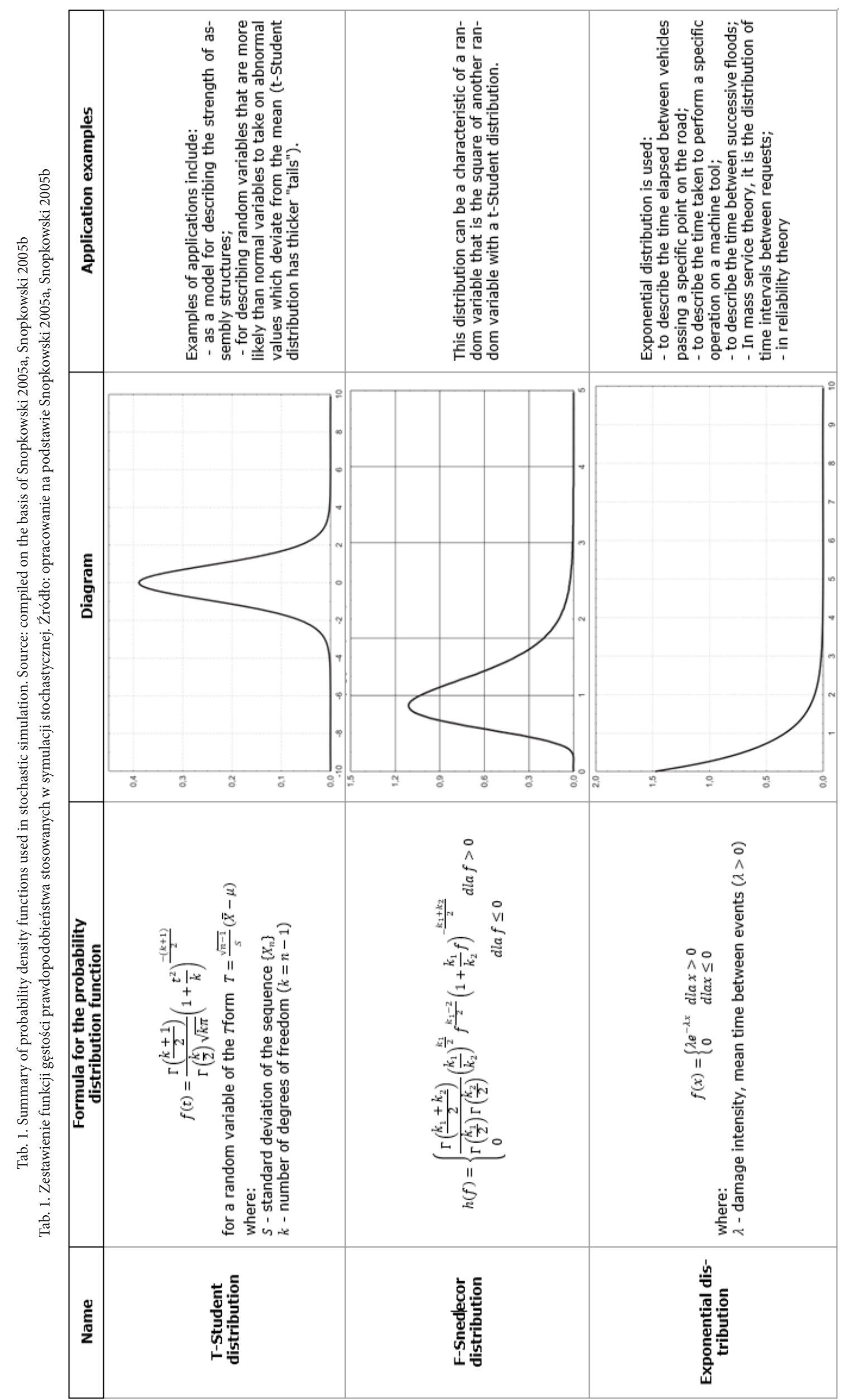


Fig. 2. Identification of probability density function $\mathrm{f}_{\mathrm{qz}}\left(\mathrm{q}_{z}\right)$ using stochastic simulation Rys. 2. Identyfikacja funkcji gęstości prawdopodobieństwa $\mathrm{f}_{\mathrm{qz}}\left(\mathrm{q}_{\mathrm{z}}\right)$ za pomocą symulacji stochastycznej

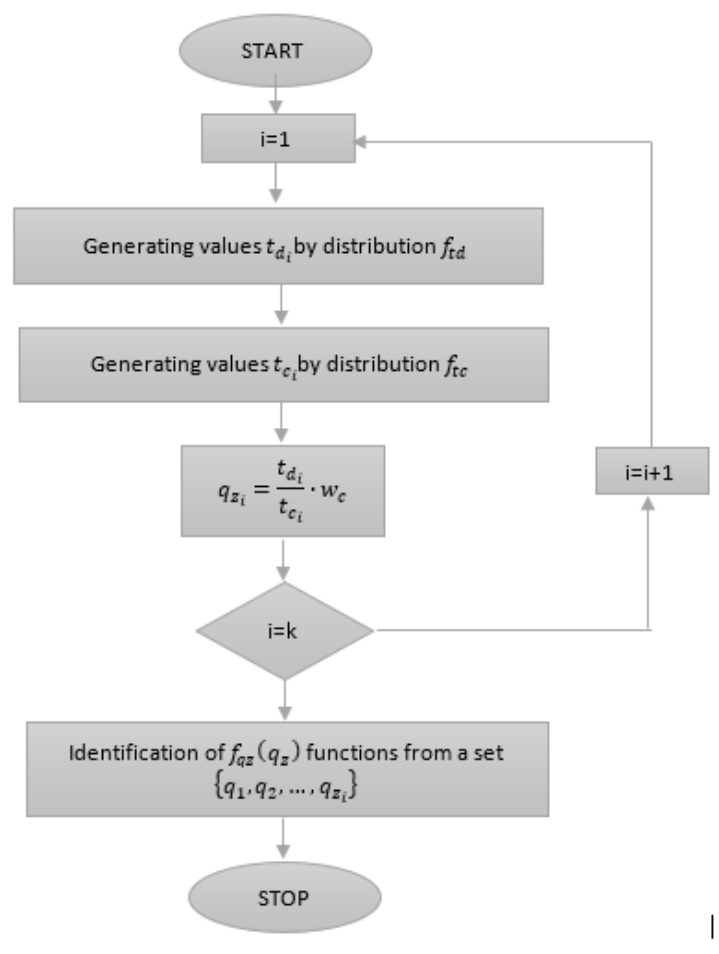

demonstrate knowledge of many issues concerning the functioning of the company and its environment. Decision making is therefore burdened with high risk. To reduce the risk of possible failure of the decision made, many different types of risk assessment methods can be used to minimize the impact of adverse aspects of both the environment and internal business conditions.

A special case of using stochastic simulation is the simulation of a mining process, in which several stages can be distinguished. The first is to determine and systematize the set of input data and to develop a mathematical model, then to determine the probability distribution of random variables and to implement the simulation of the process and finally to analyze the simulation results obtained. Among the data necessary for the simulation are geological-mining, technical-organizational and financial data.

\subsection{Identifying the probability distribution of ex- traction}

A method of identifying the probability distribution of extraction (obtained from a longwall face) is an example of the possibility of using stochastic simulation in the analysis of a production process.

The output obtained depends on the number of cuts made by the shearer during the working shift. This relationship is described by the following formula:

$\mathrm{Q}_{\mathrm{z}}=\mathrm{w}_{\mathrm{c}} \cdot \mathrm{T}_{\mathrm{d}} / \mathrm{T}_{\mathrm{c}}$

where:

$\mathrm{Q}_{\mathrm{z}}$ - extraction per shift $[\mathrm{Mg} / \mathrm{shift}]$

$\mathrm{w}_{\mathrm{c}}$ - output from a production cycle $[\mathrm{Mg} / \mathrm{zm}]$.

$\mathrm{T}_{\mathrm{d}}-$ shift availability time $[\mathrm{min} / \mathrm{zm}]$
$\mathrm{T}_{c}$ - production cycle time $[\mathrm{min} / \mathrm{cycle}]$

Production cycle output is calculated according to the formula:

$\mathrm{w}_{\mathrm{c}}=\mathrm{l} \cdot \mathrm{h} \cdot \mathrm{z} \cdot \gamma$

where:

1 - length of the longwall face [m],

$\mathrm{h}$ - height of the longwall face $[\mathrm{m}]$,

$\mathrm{z}$ - production cycle take-up $[\mathrm{m}]$,

$\gamma$ - volumetric coal weight $\left[\mathrm{Mg} / \mathrm{m}^{3}\right]$.

The production from the production cycle $\mathrm{w}_{\mathrm{c}}$ for given geological parameters of the face is a constant quantity. The quotient $\mathrm{T}_{d} \mathrm{i} \mathrm{T}_{\mathrm{c}}$, on the other hand, determines the number of production cycles that are performed during a work shift, i.e:

$L_{-} c=T_{d} / T_{c}$

Variables $\mathrm{T}_{d}$ and $\mathrm{T}_{c}$ have a direct impact on the level of extraction, and are also random variables because their values cannot be predicted with certainty before each work shift. Formula in (1) defines the relationship between three random variables, i.e. $Q_{z}, T_{d}$ i $T_{c}$.

The identification of an extraction probability distribution occurs when its probability density function is determined. In doing so, one can use the well-known theorem:

Theorem 1 . If Xis a continuous random variable with density centered on an interval $(a, b)$ and $y=g(x)$, and is a strictly monotonic function of the $C^{1}$ class with derivative on $g^{\prime} \neq 0$ that interval while $x=h(y)$ being the inverse of $y=g(x)$, then the density $k$ of the continuous random variable $Y=g(x)$ is oin the form of

$k(y)=f[h(y)]\left|h^{\prime}(y)\right|$ 
Fig. 3. Schematic diagram of calculation of output stream intensity index for a two-way shearer cutting technology Rys. 3. Schemat ideowy obliczania wskaźnika natężenia strugi wyjściowej dla technologii cięcia kombajnem dwukierunkowym

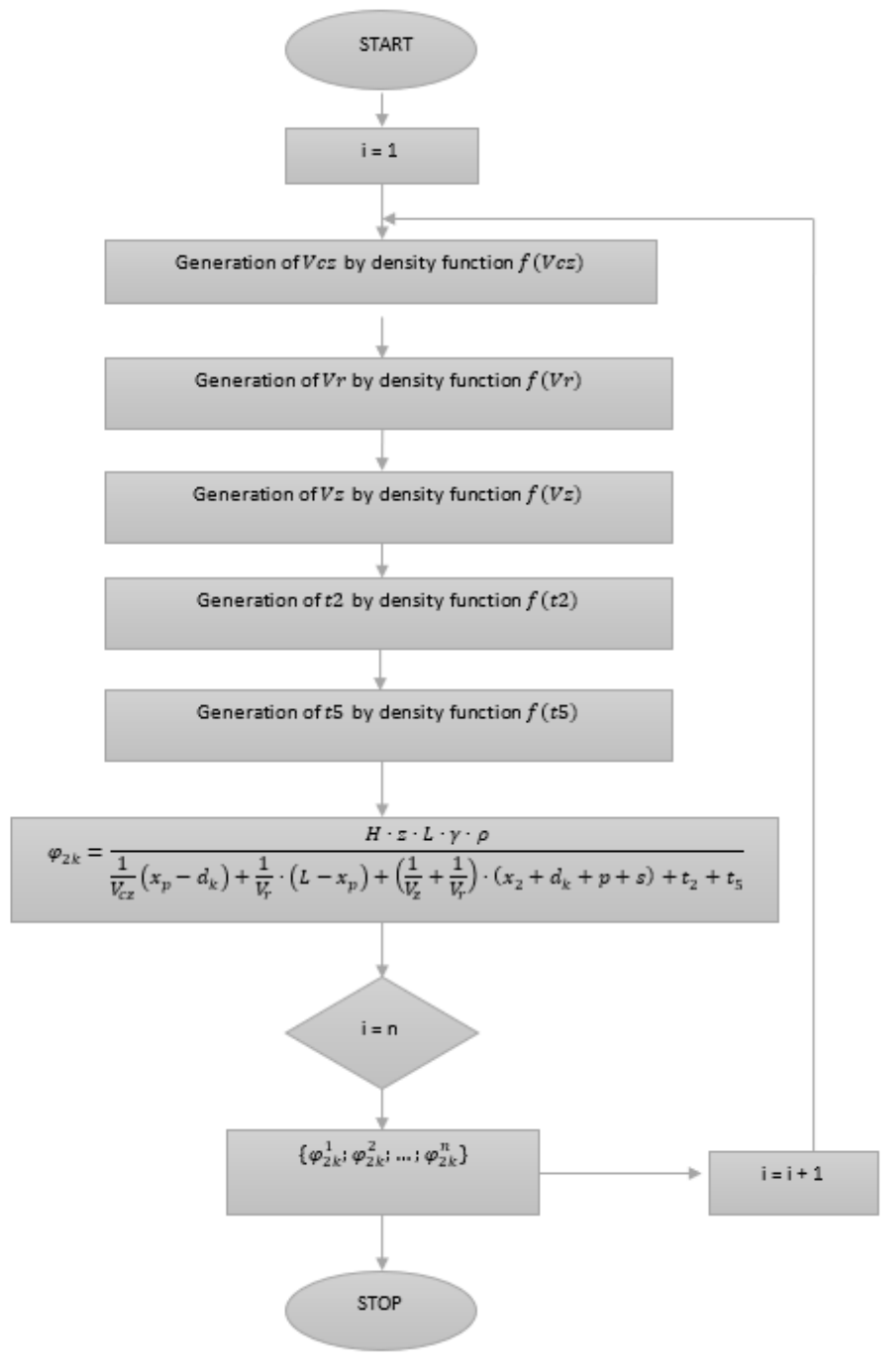

For $c<y<d$, for the remaining yfunction, $k(y)=0$ where $c=\min \left(c_{1}, d_{1}\right) d=\max \left(c_{1}, d_{1}\right), c_{1}=(\lim )_{(x \rightarrow a+0)} g(x) c d_{1}=(\lim )_{(x \rightarrow b-0)} g(x)$.

Identification of the probability distribution for extraction consists in obtaining the probability density function for a random variable $\mathrm{Q}_{\mathrm{z}}$ defined by the relation

$Q_{z}=w_{c} \cdot L_{c}$

which is a strictly monotonic linear (increasing) function and satisfies the assumptions of Theorem 1.

The inverse of this function is the $\mathrm{L}_{\mathrm{c}}=\left(1 / \mathrm{w}_{\mathrm{c}}\right) \mathrm{Q}_{\mathrm{z}}$ function , and its derivative is $L_{c}{ }^{\prime}=1 / w_{c}$. Furthermore, it should be noted that output per cycle $\mathrm{w}_{\mathrm{c}}$ is always greater than zero, so by Theorem 1, the probability density function of the random variable $\mathrm{Q}_{\mathrm{z}}$ can be written as:

$$
f_{q_{z}}\left(q_{z}\right)=\frac{1}{w_{c}} \cdot f_{l_{c}}\left(\frac{q_{z}}{w_{c}}\right) \quad \text { for } q_{z} \in R^{+}
$$

where:

$\mathrm{f}_{\mathrm{qz}}\left(\mathrm{q}_{\mathrm{z}}\right)$ - probability density function of a random variable $\mathrm{Q}_{\mathrm{z}}$ of mining per shaft,

$\mathrm{f}_{\mathrm{lc}}\left(\mathrm{q}_{\mathrm{z}} / \mathrm{w}_{\mathrm{c}}\right)$ - probability density function of the variable $\mathrm{L}_{\mathrm{c}}$ of number of production cycles per work shift.

As the variable $\mathrm{L}_{\mathrm{c}}$ can also be represented by equation (3) then its probability density function $\mathrm{f}_{\mathrm{lc}}$ can be determined using the following theorem:

Theorem 2. If random variable $U$ is the quotient of random variables $X$ and $Y$ i.e. $U=X / Y$, then the quotient density of $k_{1}$ random variables $X, Y$ is given by the formula

$k_{1}(u)=\int_{-\infty}^{\infty} f(u y, y)|y| d y$

and when $\mathrm{X}$ and $\mathrm{Y}$ are independent random variables with densities $\mathrm{f}_{1}$ and $\mathrm{f}_{2}$ then

$k_{1}(u)=\int_{-\infty}^{\infty} f_{1}(u y) f_{2}(y)|y| d y$

If we assume that the independent random variables $T_{d}$ and $T_{c}$ are characterized by the following probability density functions and respectively, $f_{t c}\left(t_{c}\right) f_{t d}\left(t_{d}\right)$ then based on equation (8), the probability density function of the random variable $\mathrm{L}_{\mathrm{c}}$ represented by equation (3) is calculated according to the following equation: 


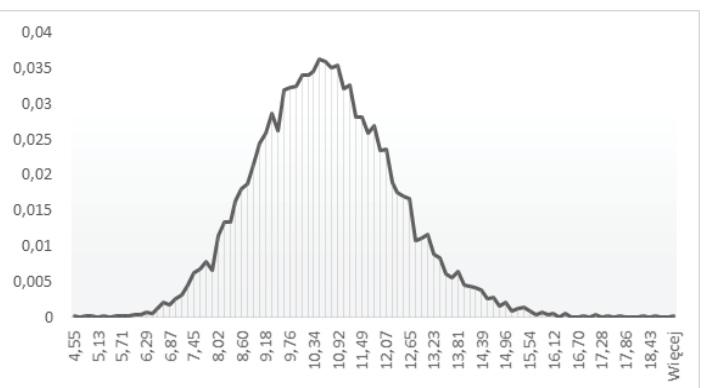

Fig. 4. Empirical probability distribution of the output flow rate $\varphi_{2 \mathrm{k}}$

Rys. 4. Empiryczny rozkład prawdopodobieństwa natężenia przepływu wyjściowego $\varphi_{2 \mathrm{k}}$

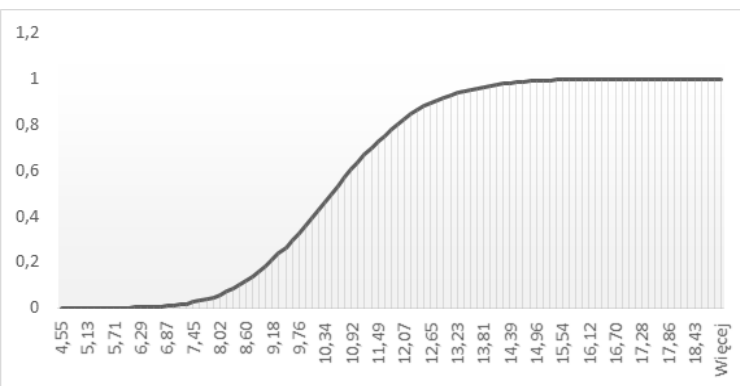

Fig. 5. Empirical distribution of the output flow rate Rys. 5. Rozkład empiryczny natężenia przepływu wyjściowego

$f_{l c}\left(l_{c}\right)=\int_{-\infty}^{\infty} f_{t d}\left(l_{c} t_{c}\right) f_{t c}\left(t_{c}\right)\left|t_{c}\right| d t_{c}$

where:

$\mathrm{f}_{\mathrm{lc}}-$ probability density function of a random variable $\mathrm{L}_{\mathrm{c}}$ of number of production cycles per shift,

$\mathrm{f}_{\mathrm{td}}$ - probability density function of a random variable $T_{d}$ of available shift time,

$\mathrm{f}_{\mathrm{tc}}$ - probability density function of the random variable $\mathrm{T}_{\mathrm{c}}$ of production cycle time.

Taking into account that random variables $\mathrm{L}_{\mathrm{c}}$ and $\mathrm{T}_{\mathrm{c}}$ take values from the set of positive real numbers, we obtain the following form of the formula

$\left\{\begin{aligned} & f_{l c}\left(l_{c}\right)=\int_{0}^{\infty} f_{t d}\left(l_{c} t_{c}\right) f_{t c}\left(t_{c}\right) t_{c} d t_{c} \quad \text { for } l_{c}>0 \\ & f_{l c}\left(l_{c}\right)=0 \text { for other instances } l_{c}\end{aligned}\right.$

By substituting the calculated form of the function into equation (6), we will obtain the following form:

$f_{q z}\left(q_{z}\right)=\frac{1}{w_{c}} \int_{0}^{\infty} f_{t d}\left(\frac{q_{z}}{w_{c}} t_{c}\right) f_{t c}\left(t_{c}\right) t_{c} d t_{c}$

The probability density function $\mathrm{f}_{\mathrm{qz}}\left(\mathrm{q}_{\mathrm{z}}\right)$ shown by the formula above identifies the probability distribution of extraction per shift. The probability density function for daily extraction is derived in a similar manner, as presented in (Snopkowski 1998).

In order to identify the probability density function of $\mathrm{f}_{\mathrm{qz}}\left(\mathrm{q}_{\mathrm{z}}\right)$ a random variable $\mathrm{Q}_{\mathrm{z}}$ using the stochastic simulation method, the block diagram shown in Figure 2 must be implemented.

The generation of a realization of random variables according to certain functions takes place within the procedures (subroutines, functions), which are part of the computer pro- gram, implementing the process of stochastic simulation. A full description of the method enabling the identification of the functions listed in the scheme can be found in (Snopkowski 2007).

The probability density function obtained as a result of the considerations carried out in this chapter $\mathrm{f}_{\mathrm{qz}}\left(\mathrm{q}_{\mathrm{z}}\right)$ can be an additional instrument for planning the production activities of an enterprise.

The formulas derived also allow for the calculation of the probability of execution or the risk of non-execution of a particular mining plan (also calculated as the probability of such event).

\subsection{Output stream intensity}

Determination of the rate of the output stream intensity as a function of probability for a production cycle realized in longwall faces of hard coal mines is another example of using stochastic simulation in the analysis of a production process.

The output flow rate $\varphi_{2 \mathrm{k}}$ is determined by the following dependence:

$\varphi_{2 \mathrm{k}}=\mathrm{W}_{\mathrm{c}} / \mathrm{T}_{\mathrm{c}}$

where:

$\mathrm{T}_{\mathrm{c}}$ - production cycle time [min],

$\mathrm{W}_{\mathrm{c}}$ - production cycle output $[\mathrm{Mg}]$ is determined by the formula:

$\mathrm{W}_{\mathrm{c}}=\mathrm{H} \cdot \mathrm{z} \cdot \mathrm{L} \cdot \gamma \cdot \rho$

in which the following parameters are:

$\mathrm{H}$ - wall height $[\mathrm{m}]$,

$\mathrm{z}$ - shearer outreach $[\mathrm{m}]$,

$\mathrm{L}$ - wall length $[\mathrm{m}]$, 
$\gamma$ - coal volumetric weight $\left[\mathrm{Mg} / \mathrm{m}^{3}\right]$,

$\rho$ - take-up utilization factor [-].

After appropriate substitutions and transformations, the formula for determining the rate of excavation takes the following form:

$\varphi_{2 k}=\frac{H \cdot z \cdot L \cdot \gamma \cdot \rho}{\frac{1}{V_{c z}}\left(x_{p}-d_{k}\right)+\frac{1}{V_{r}} \cdot\left(L-x_{p}\right)+\left(\frac{1}{V_{z}}+\frac{1}{V_{r}}\right) \cdot\left(x_{2}+d_{k}+p+s\right)+t_{2}+t_{5}}$

where:

$\mathrm{V}_{\mathrm{cz}}$ - shearer maneuvering speed (shearer speed when clearing the shearer route) $[\mathrm{m} / \mathrm{min}]$,

$\mathrm{V}_{\mathrm{r}}$ - shearer working speed $[\mathrm{m} / \mathrm{min}]$,

$\mathrm{V}_{\mathrm{z}}$ - shearer working speed when cutting $[\mathrm{m} / \mathrm{min}]$,

$\mathrm{x}_{\mathrm{p}}$ - distance from the shearer stop position to the junction between the longwall and the gate road $[\mathrm{m}]$,

$\mathrm{x}_{2}$ - distance of the advancing conveyor from support [m],

$\mathrm{p}$ - minimum distance of the advancing conveyor from the shearer $[\mathrm{m}]$,

$\mathrm{d}_{\mathrm{k}}$ - shearer length $[\mathrm{m}]$,

$t_{2}, t_{5}$ - travel times for the crossover (drive) [min].

The calculation scheme to be carried out to determine the intensity of the output stream as a function of probability consists of the following steps:

Step I: Stochastic simulation of the index $\varphi_{2 \mathrm{k}}$ for the assumed random variables, which is performed according to the scheme shown in Figure 3.

Step II: Determination of the empirical probability distribution of the index $\varphi_{2 \mathrm{k}}$, which is graphically shown in Figure 4 .
Step III: Determination of the empirical distribution of the index $\varphi_{2 \mathrm{k}}$ (Figure 5).

Determination of the empirical probability distribution of the output flow rate $\varphi_{2 \mathrm{k}}$ (stage II of the calculation) and the empirical distribution of the rate $\varphi_{2 \mathrm{k}}$ (stage III of the calculation), makes it possible to evaluate the effectiveness of the production cycle (in essence, the evaluation of the rate of the stream of excavated material) as a function of probability.

\section{Summary}

Stochastic simulation is a research method offering many advantages. One of the most important ones is the ability to "observe" the studied process, using its computer model for this purpose. Running the model (simulation) multiple times makes it possible to obtain characteristics that are achievable by observing the real process over a long period of time, which in many cases is not possible. Stochastic simulation provides an answer to the question "what happens if...". What happens to the transportation system if we introduce one-way traffic in parts of it, where traffic jams will occur, what will be the average travel time, etc. What happens to a manufacturing system if we introduce machines with different reliability characteristics, to what extent will this affect its performance as a system.

This paper presents the use of simulation to identify the probability distributions of the extraction and the output flow rate obtained in the production process as an example of a stochastic simulation of the production process. 


\section{Literatura - References}

1. Asmussen S., Glynn P.W. Stochastic Simulation, Algorithms and Analysis, Springer 2007.

2. Beaverstock M., Greenwood A., Lavery E., Nordgren W. Symulacja stosowana : modelowanie i analiza przy wykorzystaniu FlexSim / Grzegorz Wróbel polish edition; Rzeszów ; Kraków: Cem-pel Consulting, 2012.

3. Bremaud P. Markov Chains: Gibbs Fields, Monte Carlo Simulation and Queues, Springer Verlag 1999

4. Checkland P. Systems thinking, System Practice. Chichester. England: John Wiley \&Sons, 1981.

5. Geyer C.J. Markov chain Monte Carlo Lecture Notes. Copyright 1998, 2005 by Charles J. Geyer

6. Geyer C.J. Practical Markov Chain Monte Carlo. Statistical Science 1992, Volume 7 (4), pp. 473-511

7. Jerrum M. Mathematical foundations of the Markov chain Monte Carlo method, In Probabilistic Methods for Algorithmic Discrete Mathematics, Springer 1998

8. Jerrum M., Sinclair A. The Markov chain Monte Carlo method: an approach to approximate counting and integration, In Approximation Algorithms for NP-hard Problems, (Dorit Hoch-baum, ed.), PWS 1996.

9. Liu J.S. Monte Carlo Strategies in Scientific Computing, Springer 2004.

10. Niemiro W. Symulacje stochastyczne i metody Monte Carlo, Uniwersytet Warszawski, 2013.

11. Ripley B.D. Stochastic Simulation, Wiley \& Sons. 1987.

12. Robert C.P., Casella G. Monte Carlo Statistical Methods, Springer 2004.

13. Robinson, S. Simulation: The Practice of Model Development and Use. Chichester. England: John Wiley \&Sons, 2004

14. Snopkowski R. Błędy i niedokładności w symulacji stochstycznej procesów - możliwości ich we-ryfikacji. Górnictwo i Geoinżynieria. Akademia Górniczo-Hutnicza. Kraków 2009.

15. Snopkowski R. Boundary Conditions for Elementary Functions of Probability Densities for the Production Process Realised in Longwalls. Archives of Mining Sciences, Polish Academy of Sci-ences, Warszawa - Kraków, Wydawnictwo Naukowe PWN, vol. 45, Issue 4, 2000

16. Snopkowski R. Funkcje zmiennych losowych - możliwości redukcji modeli stochastycznych, Cz. 1 - Functions of random variables - possibility of reduction of stochastic models, Pt. 1. Górnictwo i Geoinżynieria. Akademia Górniczo-Hutnicza im. Stanisława Staszica, Kraków 2005

17. Snopkowski R. Funkcje zmiennych losowych - możliwości redukcji modeli stochastycznych, Cz. 2 - Functions of random variables - possibility of reduction of stochastic models, Pt. 2 Górnictwo i Geoinżynieria. Akademia Górniczo-Hutnicza im. Stanisława Staszica, Kraków 2005

18. Snopkowski R. Identyfikacja rozkładu prawdopodobieństwa wydobycia- ogólny schemat obli-czeń. AGH University of Science and Technology, Kraków 1998

19. Snopkowski R. Symulacja stochastyczna. Akademia Górniczo-Hutnicza Uczelniane Wydawnic-twa Naukowo-Dydaktyczne. Kraków 2007

20. Snopkowski R., Napieraj A. Method of the production cycle duration time modeling within hard coal longwall faces. Archives of Mining Sciences 2012, vol. 57 no. 1, s. 121-138.

21. Zieliński R., Wieczorkowski R. Komputerowe generatory liczb losowych, WNT, Warszawa 1997. 